\title{
A novel hybrid aspirin-NO-releasing compound inhibits TNFalpha release from LPS-activated human monocytes and macrophages
}

\author{
Catriona M Turnbull ${ }^{1}$, Paolo Marcarino ${ }^{2}$, Tara A Sheldrake ${ }^{4}$, \\ Loretta Lazzarato ${ }^{2}$, Clara Cena ${ }^{2}$, Roberta Fruttero ${ }^{2}$, Alberto Gasco ${ }^{2}$, \\ Sarah Fox ${ }^{4}$, Ian L Megson ${ }^{3}$ and Adriano G Rossi*4
}

\begin{abstract}
Address: ${ }^{1}$ Centre for Cardiovascular Science Queen's Medical Research Institute, University of Edinburgh, Edinburgh, EH16 4TJ, UK, ${ }^{2}$ Dipartimento di Scienza e Tecnologia del Farmaco, Università degli Studi di Torino, Turin, Italy, ${ }^{3}$ Free Radical Research Facility, UHI Millennium Institute, Inverness, IV2 3BL, UK and ${ }^{4} \mathrm{MRC}$ Centre for Inflammation Research, Queen's Medical Research Institute, University of Edinburgh, Edinburgh, EH16 4TJ, UK

Email: Catriona M Turnbull - catriona.scott@ed.ac.uk; Paolo Marcarino - paolo.marcarino@unito.it;

Tara A Sheldrake - Tara.Sheldrake@ed.ac.uk; Loretta Lazzarato - loretta.lazzarato@unito.it; Clara Cena - clara.cena@unito.it; Roberta Fruttero - roberta.fruttero@unito.it; Alberto Gasco - alberto.gasco@unito.it; Sarah Fox - sfox1@staffmail.ed.ac.uk; Ian L Megson - ian.megson@uhi.ac.uk; Adriano G Rossi* - a.g.rossi@ed.ac.uk

* Corresponding author
\end{abstract}

Published: 31 July 2008

Journal of Inflammation 2008, 5:12 doi:10.1 186/1476-9255-5-12
Received: 6 March 2007

Accepted: 31 July 2008

This article is available from: http://www.journal-inflammation.com/content/5///12

(c) 2008 Turnbull et al; licensee BioMed Central Ltd.

This is an Open Access article distributed under the terms of the Creative Commons Attribution License (http://creativecommons.org/licenses/by/2.0), which permits unrestricted use, distribution, and reproduction in any medium, provided the original work is properly cited.

\begin{abstract}
Background: The cytoprotective nature of nitric oxide (NO) led to development of NO-aspirins in the hope of overcoming the gastric side-effects of aspirin. However, the NO moiety gives these hybrids potential for actions further to their aspirin-mediated anti-platelet and anti-inflammatory effects. Having previously shown that novel NO-aspirin hybrids containing a furoxan NO-releasing group have potent anti-platelet effects, here we investigate their anti-inflammatory properties. Here we examine their effects upon TNF $\alpha$ release from lipopolysaccharide (LPS)-stimulated human monocytes and monocyte-derived macrophages and investigate a potential mechanism of action through effects on LPS-stimulated nuclear factor-kappa B (NF-kB) activation.
\end{abstract}

Methods: Peripheral venous blood was drawn from the antecubital fossa of human volunteers. Mononuclear cells were isolated and cultured. The resultant differentiated macrophages were treated with pharmacologically relevant concentrations of either a furoxan-aspirin (B8, B7; $10 \mu \mathrm{M})$, their respective furazan NO-free counterparts (BI6, BI5; $10 \mu \mathrm{M})$, aspirin $(10 \mu \mathrm{M})$, existing nitroaspirin (NCX4016; $10 \mu \mathrm{M})$, an NO donor (DEA/NO; $10 \mu \mathrm{M})$ or dexamethasone (I $\mu \mathrm{M})$, in the presence and absence of LPS $(10 \mathrm{ng} / \mathrm{ml} ; 4 \mathrm{~h})$. Parallel experiments were conducted on undifferentiated fresh monocytes. Supernatants were assessed by specific ELISA for TNF $\alpha$ release and by lactate dehydrogenase (LDH) assay for cell necrosis. To assess NF-KB activation, the effects of the compounds on the loss of cytoplasmic inhibitor of NF- $\kappa B, I \kappa B \alpha$ (assessed by western blotting) and nuclear localisation (assessed by immunofluorescence) of the $\mathrm{p} 65$ subunit of NF-kB were determined.

Results: B8 significantly reduced TNF $\alpha$ release from LPS-treated macrophages to $36 \pm 10 \%$ of the LPS control. B8 and BI6 significantly inhibited monocyte TNF $\alpha$ release to $28 \pm 5$, and $49 \pm 9 \%$ of control, respectively. The $B 8$ effect was equivalent in magnitude to that of dexamethasone, but was not shared by $10 \mu \mathrm{M}$ DEA/NO, B7, the furazans, aspirin or NCX40 I6. LDH assessment revealed 
none of the treatments caused significant cell lysis. LPS stimulated loss of cytoplasmic $1 \kappa B \alpha$ and nuclear translocation of the p $65 \mathrm{NF}-\mathrm{kB}$ subunit was inhibited by the active NO-furoxans.

Conclusion: Here we show that furoxan-aspirin, B8, significantly reduces TNF $\alpha$ release from both monocytes and macrophages and suggest that inhibition of NF- $\kappa$ B activation is a likely mechanism for the effect. This anti-inflammatory action highlights a further therapeutic potential of drugs of this class.

\section{Background}

Aspirin (acetylsalicylic acid) was first synthesized in 1899 and was the first example of the family of nonsteroidal anti-inflammatory drugs (NSAIDs). Its therapeutic uses include the treatment of headache, rheumatic pain and inflammation, in addition to being utilised as an effective prophylactic against thrombotic events in the cardiovascular system. The anti-inflammatory effects of aspirin are achieved primarily through inhibition of cyclooxygenasemediated synthesis of pro-inflammatory prostanoids [1]; it causes irreversible inhibition by selectively and rapidly acetylating a serine residue (Ser 530) near the C-terminus of the cyclooxygenase (COX) family of enzymes, forming an impediment to the binding of arachidonic acid [2-4]. The acetylation evokes a requirement for new COX to be synthesised for subsequent production of prostaglandins. Unfortunately, gastrointestinal disorders, including ulceration, are a common side-effect of aspirin, limiting its long-term use [5-8]. The effect is primarily believed to be due to inhibition of the production of prostaglandins that normally protect the gastric mucosa [8-11].

Aspirin esters containing a nitric oxide (NO)-donor moiety overcome the gastric side-effects $[12,13]$ likely via the cytoprotective effects of drug-derived NO. NO increases blood flow in the gastric mucosa, promoting repair and removal of toxins [14]. NO also increases secretion of protective gastric mucus [15] and is thought to promote healing of gastric ulcers by promoting angiogenesis [16]. Alternatively, or in addition, the protective effects of NOaspirin could be due to masking of the carboxylic acid moiety by the ester function $[12,17]$. Two main subtypes of NO-aspirins have so far been developed: the nitrooxy ester (organic nitrate) derivatives and the furoxan derivatives. The first NO-aspirin hybrid drugs to be synthesised, the $\mathrm{NiCOx}^{\otimes}$ compounds, NCX4016 (3-(nitroxymethyl)phenyl 2-(acetoxy)benzoate; Fig. 1a) and the related, NCX4215 [18] are both nitrooxy ester derivatives of aspirin, often referred to as "nitroaspirins". More recently, another series of NO-aspirin hybrid drugs, the furoxan derivatives, which utilise a furoxan NO-donor moiety have been developed $[12,19]$. These drugs link an NOdonating moiety (furoxan group) by ester linkage to the aspirin molecule (Fig. 1b). Furoxan hybrids of aspirin with NO donor moieties have shown some benefit in avoiding acute gastric injury [12], and to be effective antiplatelet agents [19]. As the compounds have been demonstrated to inhibit COX, they have the potential to retain an aspirin-like anti-inflammatory action. Through their NO release [19], these drugs gain further potential to be anti-inflammatory through the multiple actions of $\mathrm{NO}$ [for review see; [20]].

This manuscript explores the impact of two of these novel hybrid compounds and of the furazan analogues, devoid of NO-release capacity (Fig. 1c), on release of the pro-

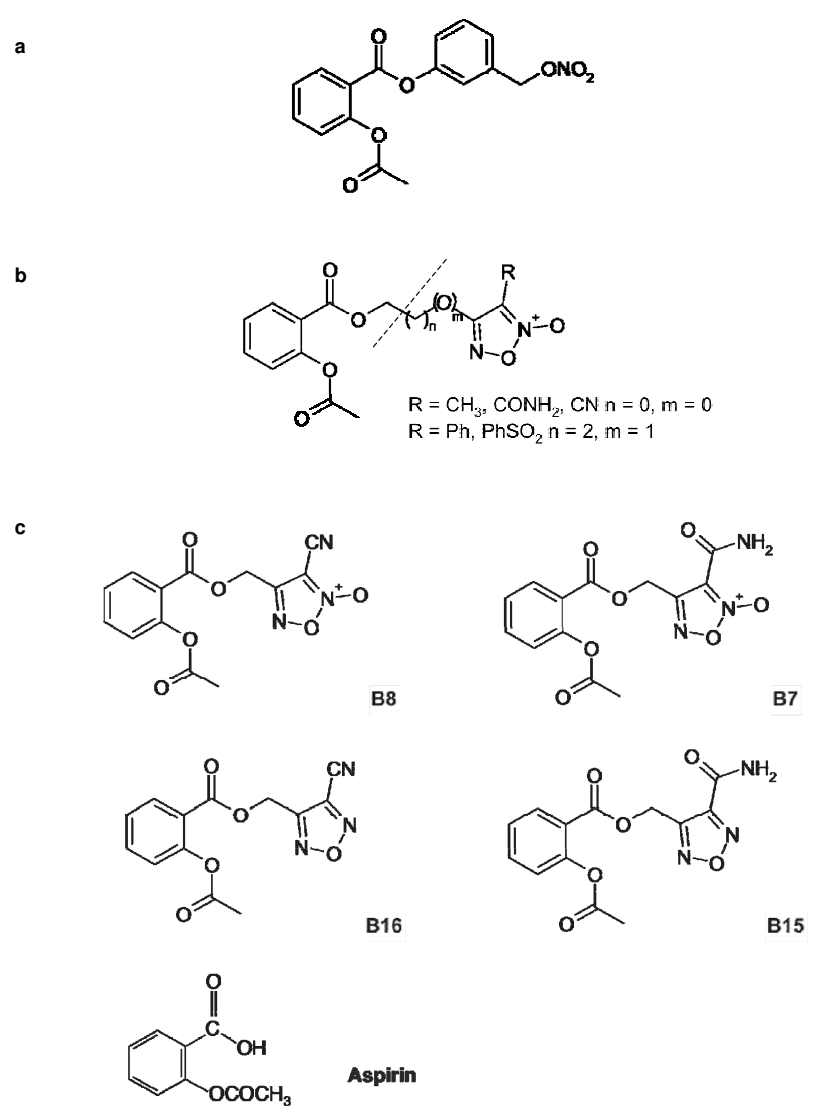

\section{Figure I}

Structural formulae: a. The structural formula of NOaspirin, NCX4016. b. The general structural formula of a furoxan-aspirin hybrid drug. C. The structural formulae of furoxans (B8 and B7), their NO-free equivalents, the furazans (BI6 and BI5) and, for comparison, aspirin. 
inflammatory cytokine, TNF $\alpha$ from human monocytederived macrophages and monocytes. Cytokines are polypeptide or glycoprotein factors that act in an autocrine and/or paracrine fashion to signal in a variety of biological processes. They are generally considered to be either pro-inflammatory (e.g. TNF $\alpha$ and interleukin (IL)8) or anti-inflammatory [e.g. TGF $\beta$ and IL-10] although they can have paradoxical actions. Cytokines act in various cell types and perform diverse functions. TNF $\alpha$ is secreted by monocytes, macrophages and neutrophils following their stimulation by bacterial LPS. The various activities of TNFa include mediation of cell adhesion molecules [21], regulation of cell death in tumour cells [22], enhancement of neutrophil responsiveness [23], control of neutrophil adherence to the endothelium [21] and synthesis of IL-1 production by macrophages [24]. LPS is known to stimulate TNF $\alpha$ production via the activation of the transcription factor, NF-кB [25-27]. It is well known that anti-inflammatory glucocorticoids such as dexamethasone can inhibit release of cytokines such as TNFa from cells stimulated with LPS [28-30]. Possible mechanisms include the ability of glucocorticoids to effectively suppress pro-inflammatory transcription factors such as NF- $\mathrm{kB}$ [31] through stimulation of glucocorticoid receptors, which subsequently translocate to the nucleus preventing histone acetylation, a vital step in the NF- $\mathrm{KB}-$ induced gene transcription [31,32]. Other mechanisms by which the glucocorticoid receptor reduces TNF $\alpha$ expression include decreasing mRNA stability, inducing expression of the inhibitor IKB, and altering co-factor (AP-1) activity [33]. NO and aspirin have both been previously shown to influence the release of TNF $\alpha$ likely through modulation of NF- $\mathrm{BB}$ function [34-42], thus hybrid NOaspirins may have increased anti-inflammatory potential through the dual action of $\mathrm{NO}$ and aspirin moieties on this pathway. Here, we set out to determine if novel NOreleasing furoxan derivatives of aspirin possess antiinflammatory properties in LPS-activated human monocyte-derived macrophages and monocytes through analysis of TNFa release and the NF- $\mathrm{KB}$ pathway. The relative contribution of the aspirin and $\mathrm{NO}$ moieties on these effects were also addressed through the use of NO-free furazan counterpart drugs, the NO donor, DEA/NO and aspirin compounds.

\section{Methods \\ Materials}

General laboratory supplies were purchased from Sigma (Poole, UK) unless otherwise stated. 2-(N,Ndiethyamino)-diazenolate-2-oxide (DEA/NO; Axxora, Nottingham, U.K.) was dissolved and stored frozen in $0.01 \mathrm{M} \mathrm{NaOH}$ prior to final dilution with phosphate-buffered saline (PBS) immediately prior to use. All NO-aspirin hybrids were synthesized at the Università degli Studi di
Torino, as described [12]. They were dissolved in dimethyl sulfoxide (DMSO) then diluted in PBS to give a final DMSO concentration $\leq 0.1 \%$.

\section{Preparation of Monocytes and Macrophages}

Peripheral venous blood was drawn from the antecubital fossa of human volunteers (non-smokers; age 20-45 years). Mononuclear cells were isolated by dextran sedimentation and discontinuous Percoll gradient centrifugation as described [43]. Mononuclear cells were resuspended at a concentration of $4 \times 10^{6} \mathrm{cells} / \mathrm{ml}$ in Iscove's DMEM. Monocytes were plated out in 48-well plates at a concentration of $2 \times 10^{6}$ per well or 6-well plates at $12 \times 10^{6}$ per well. After $1 \mathrm{~h}$, non-adherent cells were removed by washing wells with Hank's buffered salt solution (HBSS). Macrophages were derived from monocytes by culturing the monocytes in Iscove's DMEM (supplemented with $10 \%$ autologous serum) at $37^{\circ} \mathrm{C}$ for a week, with the medium being changed after 3-4 days [44].

\section{Stimulation of Cells}

For macrophages, on day 7 , the medium in each well was changed and fresh medium containing $10 \mu \mathrm{M}$ test drug or a DMSO vehicle control added to wells with or without the inflammatory stimulant, LPS $(10 \mathrm{ng} / \mathrm{ml})$. Drug concentrations were selected based on results from pilot studies and on realistic plasma concentrations, where these data are available; $10 \mu \mathrm{M}$ was deemed a relevant plasma level for aspirin, and so was utilised in this study. In order to facilitate direct comparisons, the effects of the hybrid compounds were also investigated at $10 \mu \mathrm{M}$. Drugs investigated were the furoxan-aspirin hybrids (3-cyanofuroxan4-yl)methyl 2-acetoxybenzoate (B8) and (3-carbamoylfuroxan-4-yl)methyl 2-acetoxybenzoate (B7), their respective NO-free counterparts (furazans), (4-cyanofurazan-3-yl)methyl 2-(acetoxy)benzoate (B16) and (4-carbamoylfurazan-3-yl)methyl 2-acetoxybenzoate (B15), nitroaspirin NCX4016, NO donor, DEA/NO or dexamethasone $(1 \mu \mathrm{M})$. Cells were then incubated at $37^{\circ} \mathrm{C}$ for 4 $\mathrm{h}$ before removal of the cell supernatants, which were subsequently frozen at $-70^{\circ} \mathrm{C}$ for future studies. The same procedure was also carried out on monocytes that had not been matured into macrophages with drug treatments and $4 \mathrm{~h}$ incubations taking place immediately after the final cell washing step of the isolation procedure.

\section{Enzyme-Linked Immunosorbent Assay (ELISA)}

A human TNFa ELISA kit was purchased from BD Biosciences (cat no; 550610) and performed as per kit instructions on the supernatants removed from macrophage or monocyte cultures. The absorbance of each well was read at $450 \mathrm{~nm}$ using a Thermo Labsystems Multiskan Ascent plate reader running Ascent software Version 2.6. 


\section{Lactate Dehydrogenase (LDH) Assay}

The cytotoxic impact of the compounds was assessed by measuring release of the enzyme LDH in the supernatant using a kit purchased from Roche (cat no. 1644 793).

\section{Western blotting for $I \kappa B \alpha$}

Using 6-well plates, mononuclear cells were prepared as above. Following washing, cells were treated with Iscove's DMEM supplemented with $10 \%$ autologous serum containing either $\mathrm{B} 8(1 \mu \mathrm{M}, 10 \mu \mathrm{M}, 20 \mu \mathrm{M}, 100 \mu \mathrm{M})$, gliotoxin $(0.1 \mu \mathrm{g} / \mathrm{ml})$, buffer or a DMSO vehicle control $(0.2 \%)$ for $30 \mathrm{~min}$ at $37^{\circ} \mathrm{C}$. LPS $(10 \mathrm{ng} / \mathrm{ml})$ or medium was then added to appropriate wells and left to incubate for a further $45 \mathrm{~min}$ as described for the immunofluorescence experiment (see below). Lysates were prepared at $4{ }^{\circ} \mathrm{C}$ using a protease inhibitor cocktail in TBS with $1 \%$ Nonidet P40 in order to minimise proteolysis problems. An aliquot of each lysate was used for total protein determination using a BCA protein assay kit (Pierce, Rockford, IL) and an equivalent of $24 \mu \mathrm{g}$ of protein per well was run on a $12 \%$ SDS-PAGE gel and transferred to PVDF. Blots were blocked with $5 \%$ skimmed milk in TBS/0.1\% Tween20 before probing with rabbit IKB- $\alpha$ (AbCam, cat no. 32518-100) [45] diluted 1:2500, incubated overnight at $4^{\circ} \mathrm{C}$. Subsequently, the blots were washed and incubated with goat anti-rabbit HRP (DakoCytomation, cat no. P0448), also diluted 1:2500, and developed using standard ECL (GE Healthcare).

\section{Immunofluorescence for NF- $\kappa B$ p65 Subunit}

Immunofluorescence for the p 65 subunit was used to visualise the translocation of NF- $\kappa$ B. Mononuclear cells were isolated and resuspended as described above. $4 \times 10^{6}(1$ $\mathrm{ml})$ cells were placed on a glass coverslip within a 6-well plate and left in an incubator $\left(37^{\circ} \mathrm{C} ; 1 \mathrm{~h}\right)$ to adhere. Nonadherent cells were then removed by washing wells with HBSS. Following washing, medium was changed to Iscove's DMEM (supplemented with $10 \%$ autologous serum) containing either gliotoxin $(0.1 \mu \mathrm{g} / \mathrm{ml}), \mathrm{B} 8$ or B16 $(20 \mu \mathrm{M})$ or no drug (DMSO $0.1 \%$ control). Cells were left to incubate $\left(37^{\circ} \mathrm{C}\right)$ for $30 \mathrm{~min}$. Drug concentration and incubation times were chosen from pilot studies that demonstrated them to give optimum results in this system. LPS $(10 \mathrm{ng} / \mathrm{ml})$ or vehicle (Iscove's DMEM supplemented with $10 \%$ autologous serum) was then added on top of the coverslip and left to incubate for a further 45 min. The cell-covered coverslips were then washed 3 times with PBS and $1 \mathrm{ml}$ of 3\% paraformaldehyde (in deionised water; $\mathrm{dH}_{2} \mathrm{O}$ ) was added and the cells left to fix (RT) for $20 \mathrm{~min}$. Coverslips were then washed a further 3 times with PBS and subsequently incubated for $10 \mathrm{~min}$ at RT with $1 \mathrm{ml}$ of $50 \mathrm{mM}$ glycine to quench any aldehyde groups. Following another 3 PBS washes, $1 \mathrm{ml}$ of blocking solution $(10 \%$ sheep serum in $0.2 \%$ fish skin gelatin (Sigma) was added to the coverslips and they were left overnight at $4^{\circ} \mathrm{C}$. The following morning, after washing the cells, $100 \mu \mathrm{l}$ of primary antibody (NF- $\mathrm{KB}$ p65 mouse anti-human, BD Biosciences cat no. 610868 [46]; 1:50 dilution in blocking solution) was added to the cells. $1 \mathrm{~h}$ later, following three PBS washes, $100 \mu \mathrm{l}$ of a 1:250 dilution (in blocking solution) of secondary antibody (Alexa Fluor $^{\oplus} 488$ goat anti-mouse IgG, Invitrogen cat no. A11001) was added and left to incubate for $1 \mathrm{~h}$ at RT in the dark. Finally, three PBS washes, followed by three $\mathrm{dH}_{2} \mathrm{O}$ washes were carried out to prevent crystal formation. Coverslips were then mounted onto slides using Moviol (Calbiochem, Merck, Nottingham, UK) and the slides were then stored in the dark at $4{ }^{\circ} \mathrm{C}$. Images from the immunofluorescence slides were captured with a camera connected to a Zeiss Axiovert S100 microscope using Improvision Openlab 3.1.5 software. Images were captured at a magnification of $\times 100$.

\section{Statistical analyses}

Statistical analysis was by 1-way analysis of variance (ANOVA) with Dunnett's post-test where applicable and was performed using GraphPad Prism version 4 (GraphPad Software, San Diego, USA). ${ }^{* *}$ is used to represent a P value $<0.01{ }^{*}$ denotes a $P$ value $<0.05$ and $P$ values greater than 0.05 were deemed not significant. Where expressed, data are in the form mean \pm standard error of the mean (S.E.M.).

\section{Results}

\section{Effect on NO-furoxans on TNF $\alpha$ Release}

B8 had a significant inhibitory effect on TNF $\alpha$ release in human monocyte-derived macrophages treated with LPS $(36 \pm 10 \%$ of LPS control, $\mathrm{P}<0.01 ; \mathrm{n}=5-10$ separate donors, Fig. 2). The effect was equivalent in magnitude to that of dexamethasone, but was not shared by DEA/NO, B7, the furazans, aspirin or NCX4016. In monocytes, B8, and to a lesser extent, its NO-free equivalent, B16, significantly inhibited TNF $\alpha$ release [to $28 \pm 5 \%(P<0.01)$, and $49 \pm 9 \%(P<0.05)$ of control respectively, $n=4-6)$. Basal $\mathrm{TNF} \alpha$ levels were $0.9 \pm 0.2 \mathrm{pg} / \mathrm{ml}$ for macrophages and 1.6 $\pm 0.4 \mathrm{pg} / \mathrm{ml}$ for monocytes. After LPS-treatment these rose to $5.5 \pm 0.5$ and $9.6 \pm 0.3 \mathrm{ng} / \mathrm{ml}$ respectively.

\section{Effect on NO-furoxans on LDH Release}

None of the treatments studied caused significant cell death (Fig. 3) compared with untreated macrophages and monocytes. Levels of LDH released following the treatments were comparable with that from untreated control samples ( $0.5 \times 10^{5}$ cells/treatment $)$.

\section{Effect on NO-furoxans on NF- $k$ B activation}

In order to investigate the potential molecular mechanism of action of the inhibitory effect of B8 on macrophage TNF- $\alpha$ release we investigated the effect of the compound on LPS-stimulated NF- $\kappa$ B activation. For this we assessed 
a

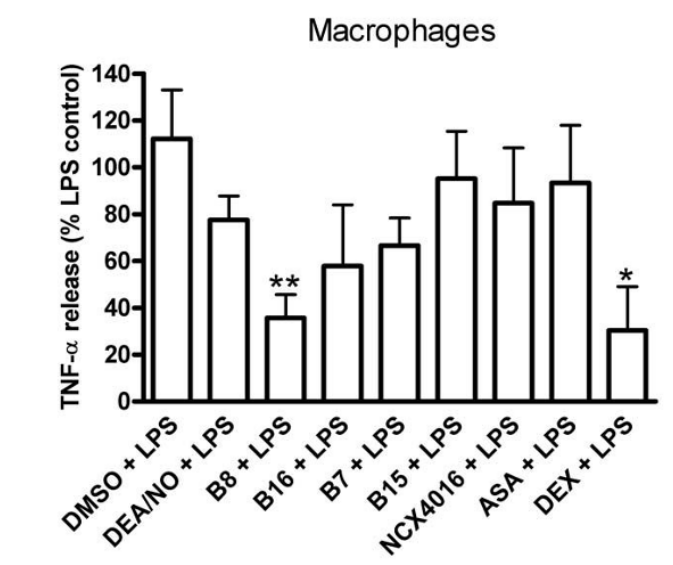

$\mathrm{b}$

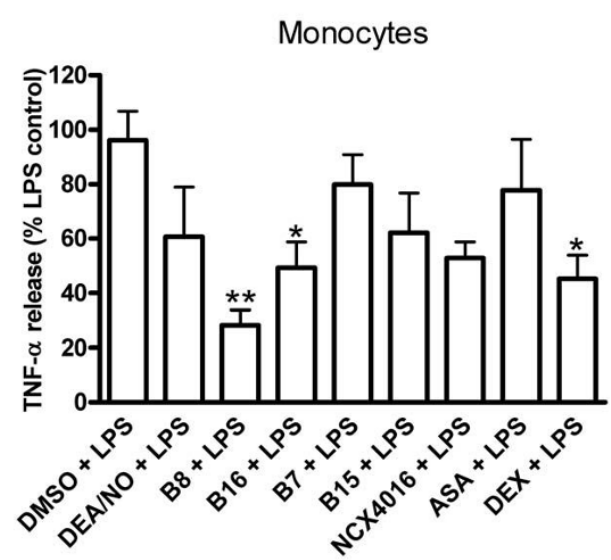

Figure 2

Effect of potential anti-inflammatory agents on LPS ( $10 \mathrm{ng} / \mathrm{ml}$ )-induced TNF $\alpha$ release in human (a) monocyte-derived macrophages and (b) monocytes after $4 \mathrm{~h}$ treatment with $10 \mu \mathrm{M}$ of either DEA/NO, B8, B I 6, B7, B I 5, NCX40 I 6 or aspirin or I $\mu$ M of dexamethasone (Dex). For macrophages $n=5-10$ and for monocytes $\mathrm{n}=4-6$ separate donors. $* *=\mathrm{p}<0.01 *=\mathrm{p}<$ 0.05 determined by One-Way ANOVA followed by Dunnett's test.

the effect of $\mathrm{B} 8$ on the loss of the cytoplasmic inhibitory subunit of NF- $\kappa \mathrm{B}, \mathrm{I} \kappa \mathrm{B} \alpha$ (Fig. $4 \mathrm{a}$ and $4 \mathrm{~b}$ shows two typical western blots of cytoplasmic I $\mathrm{I} B \alpha$ ). In both blots LPS causes a dramatic loss of cytoplasmic $I \kappa B \alpha$, an effect that was completely inhibited by the NF- $\mathrm{B}$ inhibitor gliotoxin. Similarly, B8 at $100 \mu \mathrm{M}$ also blocked LPS-induced

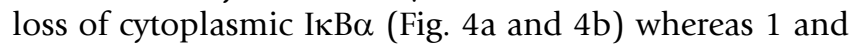
$10 \mu \mathrm{M}$ B8 (Fig. 4b) did not affect LPS loss of I $\mathrm{B}$. The concentration of $\mathrm{B} 8$ that appears to be on the threshold of inhibition appears to be around $20 \mu \mathrm{M}$ (Fig. 4a). In order

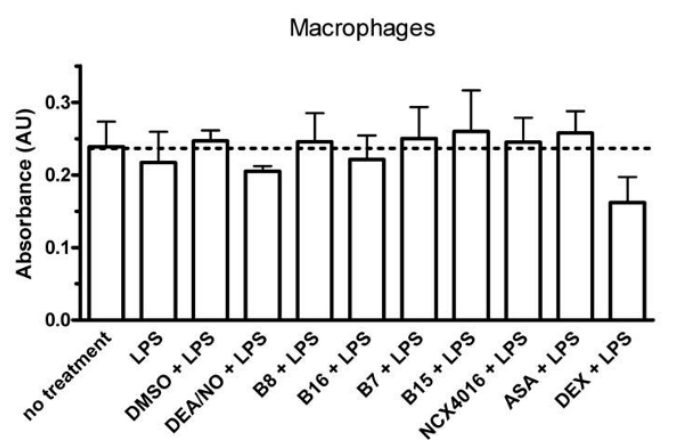

b

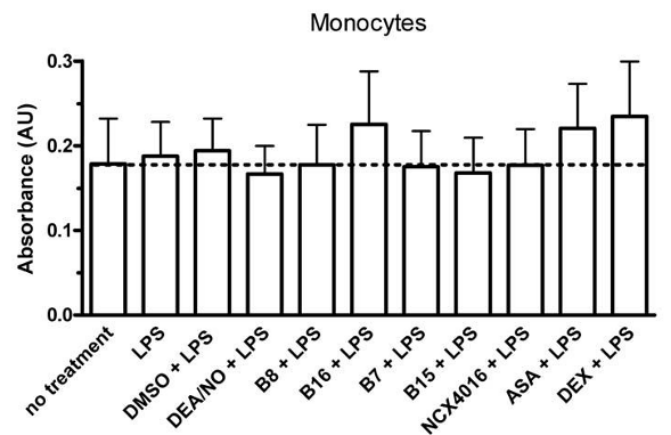

Figure 3

Bar graphs show LDH measurement in (a) monocyte-derived macrophages and (b) monocyte supernatants after treatment with $10 \mu \mathrm{M}$ of either DEA/ NO, B8, B I 6, B7, B I 5, NCX40 I 6 or aspirin or I $\mu$ M of dexamethasone (Dex) and stimulated with LPS ( 10 $\mathrm{ng} / \mathrm{ml}$ ). For macrophages $n=5-15$ and for monocytes $n=6$ separate donors. One-way ANOVA revealed that there were no significant differences between groups in either cell type.

to confirm that $\mathrm{B} 8$ inhibits $\mathrm{NF}-\kappa \mathrm{B}$ activation more directly, we used immunofluorescence to investigate its effect on LPS stimulation of NF- $\kappa$ B p 65 subunit translocation from the cytoplasm to the nucleus. NF- $\kappa \mathrm{B}$ p 65 immunofluorescence revealed that the subunit location varied according to the drug treatment. Control cells displayed uniform staining throughout the cytoplasm, but following stimulus with LPS, strong staining was observed in the nucleus and much less in the cytoplasm (Fig. 5a, b). Incubation with gliotoxin before the LPS stimulus inhibited the nuclear translocation of p 65 as demonstrated by the presence of cytoplasmic staining (Fig. 5c). Pre-incubation with the NO-aspirin $\mathrm{B} 8$ gave a dramatic shift in the staining compared to the LPS control. Location of the NF$\kappa \mathrm{B}$ p65 subunit was now revealed to be cytoplasmic (Fig. $5 \mathrm{~d})$. Cells treated with the NO-free equivalent of B8, B16, 


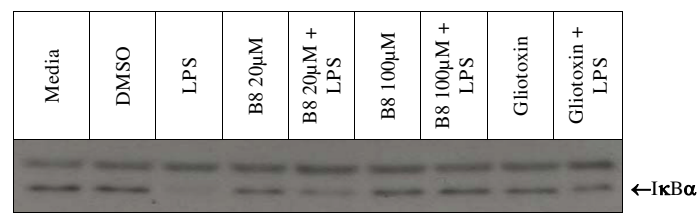

b

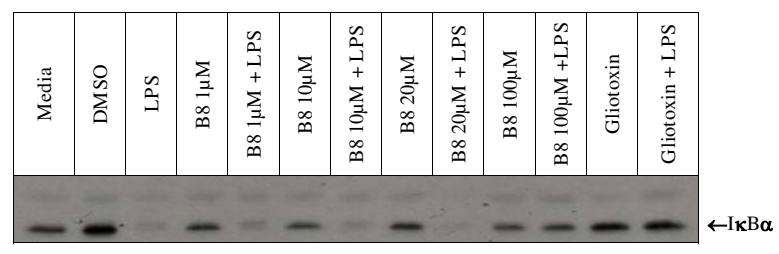

Figure 4

Western blots showing the effects of varying concentrations of $\mathbf{B} 8$ on $I \kappa B \alpha$. Mononuclear cells were prepared as per methods, plated on 6-well plates, allowed to adhere for I $\mathrm{h}$ then treated with varying concentrations of B8 (I $\mu \mathrm{M}$, $10 \mu \mathrm{M}, 20 \mu \mathrm{M}, 100 \mu \mathrm{M})$, gliotoxin $(0.1 \mu \mathrm{g} / \mathrm{ml})$, buffer or a DMSO vehicle control $(0.2 \%)$ for $30 \mathrm{~min}$ at $37^{\circ} \mathrm{C}$. After this interval LPS ( $10 \mathrm{ng} / \mathrm{ml})$ or buffer was added to appropriate wells and left to incubate for a further $\mathbf{4 5} \mathrm{min}$. Lysates were prepared, total protein determined and $24 \mu \mathrm{g}$ of protein per well was run on a I2\% SDS-PAGE gel, transferred to PVDF. Blots were blocked before probing with rabbit $I_{\kappa} B-\alpha$ diluted $\mathrm{I}: 2500$, incubated overnight at $4^{\circ} \mathrm{C}$. Subsequently, the blots were washed and incubated with goat anti-rabbit HRP, also diluted I:2500, then developed using standard ECL. Blots are representative of at least 6 similar experiments.

displayed cytoplasmic staining but with a greater amount of nuclear staining than B8 treated cells (Fig. 5e).

\section{Discussion}

Impact of NO-furoxans on TNF $\alpha$-Release by Macrophages and Monocytes

The NO-aspirin, B8, had a significant inhibitory effect on TNF- $\alpha$ release from human monocyte-derived macrophages treated with LPS. In monocytes B8, and to a lesser extent, its NO-free equivalent, B16 again caused significant inhibition of TNF- $\alpha$ release. In monocyte-derived macrophages, the lack of effects of B16 and aspirin suggest that the inhibitory effect of $\mathrm{B} 8$ on TNF $\alpha$ release is NOmediated. However, as this effect is not mimicked by the NO-donor, DEA/NO, it is apparently a specific property of B8 that is possibly related to amount, duration or site of NO release. The possibility of diminished release of TNF $\alpha$ by B8-treated cells being simply due to a cytotoxic effect of the compound was not supported by results from the LDH assay. None of the treatments significantly affected cell death when compared with untreated cells. a

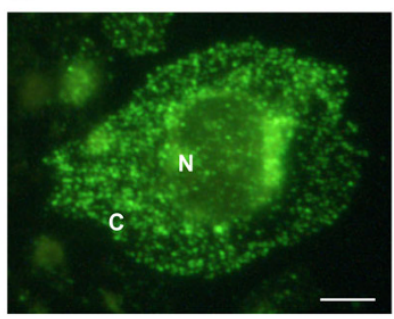

b

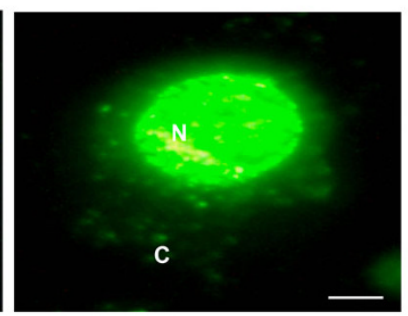

C

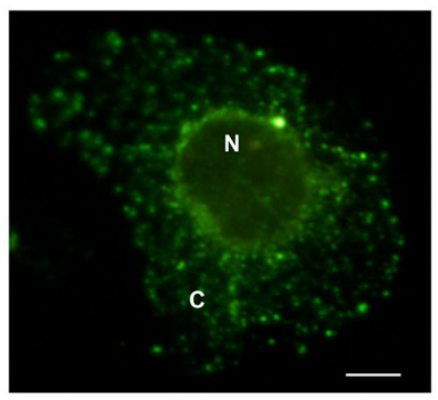

d

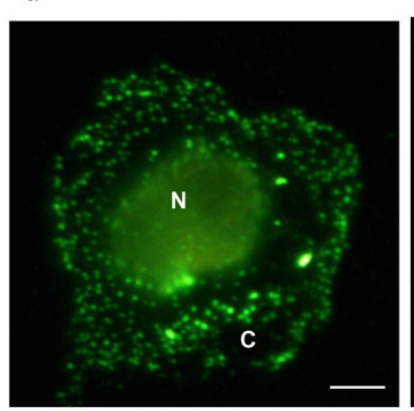

e

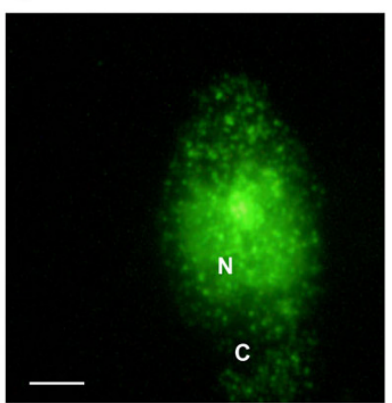

Figure 5

Representative immunofluorescence images. Image a shows a control treated monocyte. Image b shows a monocyte following a 45 min LPS stimulus. Image c shows a monocyte treated with gliotoxin $(0.1 \mu \mathrm{g} / \mathrm{ml}, 30 \mathrm{~min})$ and stimulated with LPS ( $10 \mathrm{ng} / \mathrm{ml}, 45 \mathrm{~min})$. Image $\mathbf{d}$ shows a monocyte treated with B8 $(20 \mu \mathrm{M}, 30 \mathrm{~min})$ and stimulated with LPS (10 $\mathrm{ng} / \mathrm{ml}, 45 \mathrm{~min})$. Image e shows a monocyte treated with BI6 (20 $\mu \mathrm{M}, 30 \mathrm{~min})$ and stimulated with LPS (10 ng/ml, $45 \mathrm{~min})$. $\mathrm{C}=$ cytoplasm. $\mathrm{N}=$ nucleus. Scale bar represents $\mathrm{I} 00 \mu \mathrm{m}$. Similar images were obtained on at least 3 separate experiments.

In monocytes, $\mathrm{TNF} \alpha$ release was inhibited by the NOaspirin, B8, but also by its NO-free furazan counterpart, B16. Aspirin showed no significant difference from the LPS control. Similar to the macrophage results, DEA/NO did not cause significant inhibition. Again, B8 could be acting via an NO-mediated mechanism specific to the amount, duration or site of $\mathrm{NO}$ release. However, the interesting observation that NO-free, B16 also causes a significant inhibition suggests a possible further mechanism. As previously demonstrated, the acetyl group of 
these compounds is lost in plasma [12], leaving salicylic acid, through which, inhibition of cytokine release has been reported [47-49]. It may therefore be possible that under these experimental conditions, a salicylic acidmediated mechanism is responsible for the inhibition of TNF $\alpha$ release observed with B8- and B16-treated cells. It is probable that the result obtained with B8 is achieved through combination of the effects of NO (as illustrated by DEA/NO) and that of the NO-free B16. We have previously shown that the furoxan-aspirin $\mathrm{B} 7$ releases significantly less NO than B8 [19] and thus suggest that the NO release from $\mathrm{B} 7$ is insufficient to result in an anti-inflammatory effect similar to that of B8. Our result obtained with B16 indicates that altering the chemical structure of aspirin clearly has an impact on the ability to achieve antiinflammatory properties in this assay. Furthermore, the alteration to the aspirin structure in B15 and B7 likely contributed to their poor performance in this assay.

In this study, aspirin did not significantly reduce TNF $\alpha$ release from LPS-stimulated monocytes or macrophages. This is consistent with a similar study in which aspirin failed to have an effect even at a 30-fold higher concentrations than was used in the present study [50]. A further study did report an inhibitory effect of aspirin on TNF $\alpha$ release from LPS-stimulated monocytes but this was at concentrations of 5-10 mM [49], which may not be representative of pharmacologically relevant plasma concentrations [51]. We show here that NCX4016 did not significantly reduce the release of TNF $\alpha$. In a study carried out by others, NCX4016 did not inhibit TNF $\alpha$ release at the same concentration used here $(10 \mu \mathrm{M})$, but was shown to inhibit the release of TNF $\alpha$ and IL-6 from LPSstimulated macrophages at higher (100 and $300 \mu \mathrm{M})$ concentrations and following a $6 \mathrm{~h}$ incubation [50]. Despite not being affected by the soluble guanylate cyclase inhibitor ODQ, the authors suggest that the inhibitory effect of NCX4016 is NO-mediated due to the failure of aspirin to inhibit cytokine release. A further study also showed that NCX4016 (again at concentrations 10-fold higher than used in this study), inhibited the release of IL-1 $\beta$ and IL18 from LPS-stimulated monocytes, via NO-mediated inhibition of the enzyme required for intracellular processing and maturation of IL-1 and IL-18 (caspase-1) activity [52]. It is likely that the differing outcomes observed between this and other studies are purely due to drug incubation time or concentrations. The concentration studied here is based on the realistic relevant plasma concentrations of aspirin [51] and so is more demonstrative of the true therapeutic potential of the drug. The results here show that at a concentration at which the furoxan compound, B8, causes a significant $72 \%$ reduction in TNFa release from monocytes and a $64 \%$ reduction from macrophages, its organic nitrate counterpart does not.
Possible explanations for the differential effects of the same treatments observed between monocytes and macrophages effect may be the differential expression and activity of receptors and signalling pathways between the two cell types. It has previously been reported that the anti-inflammatory effect of IL-4 on the release of TNF $\alpha$ and other cytokines, varies between LPS-stimulated monocytes and macrophages [53]. This effect is due to loss of a receptor for IL-4 during monocyte differentiation [53]. Other differences reported between monocytes and macrophages include those showing that LPS activates cytosolic PLA $\mathrm{A}_{2}$ in monocytes but not in macrophages. A similar activation in monocytes, but not macrophages, is seen after LPS-stimulation in the following signalling pathways: the MAP kinase, ERK, phosphatidylinositol-3 kinase and p70S6 kinase [54,55]. Further variations include increased expression of $\mathrm{Ca}^{2+}$-dependent protein kinase $\mathrm{C}$ isoforms in monocytes when compared to macrophages [56] and also that maturation into macrophages results in slower production of the cytokine, IL-1 $\beta$ [57]. It is, therefore, possible that changes such as these to receptor expression, signalling pathways and to the biosynthesis of cytokines, which normally occur during the maturation of monocytes with macrophages, may impact on the ability of the studied compounds to have a significant effect.

\section{Impact of NO-furoxans on NF- $\kappa$ B Activation in Monocytes}

The western blot and immunofluorescence experiments further suggested a possible mechanism for the B8-mediated inhibition of TNF $\alpha$ release. The transcription factor, $N F-\kappa B$, exists as a dimer (can be either a homodimer or heterodimer). The most common form is a heterodimer composed of the p65/p50 subunits [58]. Normally, NF- $\kappa B$ is kept in an inactive state in the cytoplasm, bound to an inhibitory subunit named I $\mathrm{B} \alpha \alpha$ [59]. The phosphorylation of I $\mathrm{B} \alpha$ by a kinase known as IKK and the subsequent degradation of $\mathrm{I} \kappa \mathrm{B} \alpha$ leads to the activation of the NF- $\kappa \mathrm{B}$ [60]. The NF- $\kappa \mathrm{B}$ dimer containing the p65 subunit; the dominant factor in the induction of the TNF $\alpha$ gene, then translocates from the cytoplasm to the nucleus where it activates transcription of target genes such as TNF $\alpha$ $[25,27,61,62]$. To investigate the effect of the NO-aspirin on stimulus (LPS)-induced NF- $\kappa \mathrm{B}$ activation, we used two independent assays; namely loss of cytoplasmic I $\mathrm{IB} \alpha$ assessed by western blotting and translocation of the p 65 subunit of NF- $\kappa \mathrm{B}$ assessed by immunofluorescence. For consistency, LPS was used as our NF- $\kappa \mathrm{B}$-activating stimulus and epipolythiodioxoperazine (gliotoxin), a known immunosuppressive agent that inhibits NF- $\kappa \mathrm{B}$ activation by preventing $\mathrm{I} \kappa \mathrm{B} \alpha$ degradation $[43,63]$, was used as the positive control. LPS caused a dramatic loss of cytoplasmic I $\kappa \mathrm{B} \alpha$ and translocation of cytoplasmic p65 to the nucleus, effects that were inhibited by NO-aspirin B8 and the positive control gliotoxin. Thus, the inhibition of NF- 
$\kappa \mathrm{B}$ activation provides a plausible explanation for the $\mathrm{B} 8$ induced reduction in TNF $\alpha$ release as observed in the ELISA studies. It has been shown that NO inhibits LPSinduced IkB-phosphorylation and inhibits the activation of NF- $\mathrm{B}$ [35], further supporting our paradigm of NOmediated inhibition of TNF $\alpha$ release by B8. B16-treated and LPS-stimulated monocytes also displayed some evidence of cytoplasmic staining, but with more nuclear staining than its NO counterpart. This result is consistent with the ELISA data, where significant inhibition of TNFa release, albeit lesser than B8-treated cells, was observed following B16 treatment.

\section{Therapeutic Implications}

The data here show that the furoxan-aspirin compound B8 has anti-inflammatory effects in LPS-stimulated monocytes and macrophages through its reduction in NF$\kappa \mathrm{B}-$-mediated TNF $\alpha$ release. This action of B8 may be useful in inflammatory diseases (arthritis, Crohn's disease and asthma [64-67] where anti-TNFo therapy is, or has potential, to be of therapeutic benefit. Rheumatoid arthritis is a chronic inflammatory autoimmune disorder characterised by inflammation of the lining (synovium) of joints. Joint deterioration, together with the pain associated with synovial inflammation can lead to substantial loss of mobility. Pro-inflammatory cytokines are abundant in the joints of sufferers [65]. Anti-TNF $\alpha$ drugs have been recently licensed for use in arthritis in a bid to limit the contribution of this cytokine to the chronic joint inflammation [67]. Treatment of arthritis with drugs of the NSAID class is severely limited due to the gastric sideeffects associated with the high doses and chronic nature of the treatment required. However it is hoped that NOaspirins might offer a preferable alternative to therapy with conventional NSAIDs. The multifaceted actions of B8 on COX inhibition [19] the anti-TNF $\alpha$ effects demonstrated here, its observed resistance to gastrotoxic effects [12] and its potential for targeted intracellular release of NO $[19,68]$ could indicate B8 to be a promising antiarthritic drug. A summary of the effects of the furoxanaspirin hybrid drugs is provided in Fig. 6. A further, more speculative application for drugs such as B8 is in atherosclerosis therapy. It is now widely accepted that inflammation is a key element in atherogenesis and atherosclerotic plaque rupture leading to acute cardiovascular events such as myocardial infarction or stroke [69]. The release of TNFa by monocytes and macrophages causes various effects involved in destabilising the atherosclerotic plaque [70-74]. Such evidence may suggest that drugs with an anti-TNF $\alpha$ action, such as B8, may be of benefit in atherosclerosis.

\section{Conclusion}

Taken together, these studies provide evidence that treatment with NO-aspirin $\mathrm{B} 8$, significantly reduced TNF $\alpha$

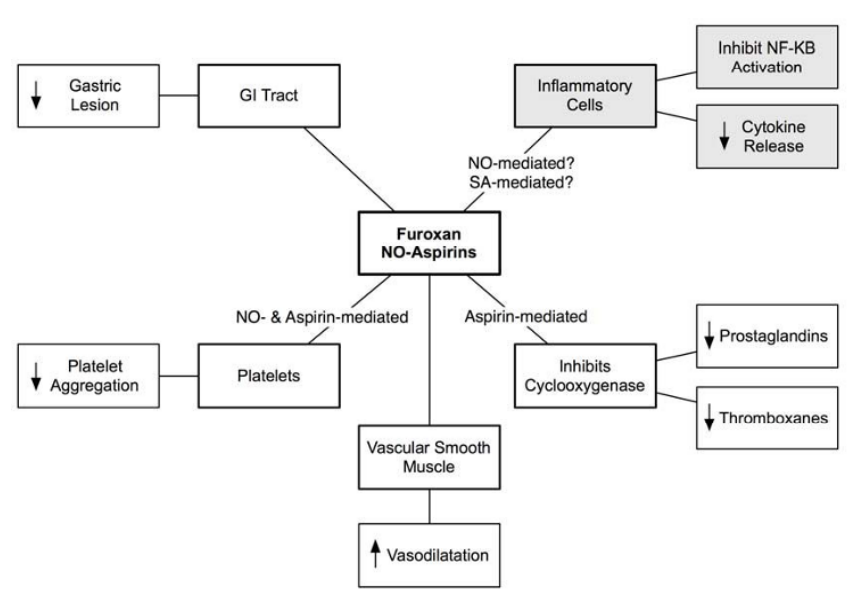

Figure 6

A schematic representation of the effects and potential uses of furoxan-aspirin hybrid drugs.

release from both LPS-stimulated monocytes and monocyte-derived macrophages. A possible mechanism for this anti-inflammatory action is through the inhibition of its transcription factor, NF- $\mathrm{\kappa B}$ by NO. Such an action instils a potential for drugs of this NO-aspirin hybrid class to be utilised as anti-inflammatory agents for the treatment of a wide range of inflammatory conditions such as arthritis.

\section{Abbreviations}

ANOVA: Analysis of variance; COX: Cyclooxygenase; DEA/NO: 2-(N,N-diethyamino)-diazenolate-2-oxide; $\mathrm{dH}_{2} \mathrm{O}$ : deionised water; DMSO: Dimethyl sulfoxide; ELISA: Enzyme-linked immunosorbent assay; HBSS: Hanks buffered salt solution; IL: Interleukin; LDH: Lactate dehydrogenase; LPS: Lipopolysaccharide; NO: Nitric oxide; NSAID: Nonsteroidal anti-inflammatory drugs; NF$\kappa B$ : Nuclear factor-kappa B; PBS: Phosphate-buffered saline; RT: Room temperature, TNFa: Tumour necrosis factor-alpha.

\section{Competing interests}

The authors declare that they have no competing interests.

\section{Authors' contributions}

The manuscript was written and the experiments were designed by CMT and AGR. CMT performed the TNF- $\alpha$ release, LDH assay and immunofluorescence experiments, PM performed the western blot experiments and TAS performed and assisted in all the experimental procedures. Hybrid drugs were synthesised and supplied by LL, CC, RF and AG. AGR and ILM supervised the experiments and oversaw manuscript construction together with SF, revising it critically for important intellectual content. All authors have given final approval of the version to be published. 


\section{Acknowledgements}

CMT was supported by a BHF Student Fellowship (FS/03/068).

\section{References}

I. Vane JR, Botting RM: The mechanism of action of aspirin. Thromb Res 2003, I I 0:255-258.

2. DeWitt DL, Smith WL: Primary structure of prostaglandin G/H synthase from sheep vesicular gland determined from the complementary DNA sequence. Proc Natl Acad Sci USA 1988, 85:1412-1416.

3. Roth GJ, Majerus PW: The mechanism of the effect of aspirin on human platelets. I. Acetylation of a particulate fraction protein. J Clin Invest 1975, 56:624-632.

4. Roth GJ, Stanford N, Majerus PW: Acetylation of prostaglandin synthase by aspirin. Proc Natl Acad Sci USA 1975, 72:3073-3076.

5. Cameron AJ: Aspirin and gastric ulcer. Mayo Clin Proc 1975, 50:565-570.

6. Seager JM, Hawkey CJ: ABC of the upper gastrointestinal tract: Indigestion and non-steroidal anti-inflammatory drugs. $\mathrm{Bmj}$ 2001, 323:1236-1239.

7. Tramer MR, Moore RA, Reynolds DJ, McQuay HJ: Quantitative estimation of rare adverse events which follow a biological progression: a new model applied to chronic NSAID use. Pain 2000, 85:169-182.

8. Wallace JL: Nonsteroidal anti-inflammatory drugs and gastroenteropathy: the second hundred years. Gastroenterology 1997, I I 2:1000-1016.

9. Robert A, Nezamis JE, Lancaster C, Hanchar AJ: Cytoprotection by prostaglandins in rats. Prevention of gastric necrosis produced by alcohol, $\mathrm{HCl}, \mathrm{NaOH}$, hypertonic $\mathrm{NaCl}$, and therma injury. Gastroenterology 1979, 77:433-443.

10. Schoen RT, Vender RJ: Mechanisms of nonsteroidal anti-inflammatory drug-induced gastric damage. Am J Med 1989, 86:449-458

II. Whittle BJ: Mechanisms underlying gastric mucosal damage induced by indomethacin and bile-salts, and the actions of prostaglandins. Br J Pharmacol 1977, 60:455-460.

12. Cena C, Lolli ML, Lazzarato L, Guaita E, Morini G, Coruzzi G, McElroy SP, Megson IL, Fruttero R, Gasco A: Antiinflammatory, gastrosparing, and antiplatelet properties of new NO-donor esters of aspirin. J Med Chem 2003, 46:747-754.

13. Fiorucci S, Del Soldato P: NO-aspirin: mechanism of action and gastrointestinal safety. Dig Liver Dis 2003, 35(Suppl 2):S9-19.

14. Wallace JL, Miller MJ: Nitric oxide in mucosal defense: a little goes a long way. Gastroenterology 2000, I I 9:5 I 2-520.

15. Brown JF, Keates AC, Hanson PJ, Whittle BJ: Nitric oxide generators and cGMP stimulate mucus secretion by rat gastric mucosal cells. Am J Physiol 1993, 265:G418-422.

16. Ma L, Wallace JL: Endothelial nitric oxide synthase modulates gastric ulcer healing in rats. Am J Physiol Gastrointest Liver Physiol 2000, 279:G34I-346.

17. Rainsford KD, Whitehouse MW: Gastric irritancy of aspirin and its congeners: anti-inflammatory activity without this sideeffect. J Pharm Pharmacol 1976, 28:599-601.

18. Wallace JL, McKnight W, Del Soldato P, Baydoun AR, Cirino G: Antithrombotic effects of a nitric oxide-releasing, gastric-sparing aspirin derivative. J Clin Invest 1995, 96:271 I-2718.

19. Turnbull CM, Cena C, Fruttero R, Gasco A, Rossi AG, Megson IL: Mechanism of action of novel NO-releasing furoxan derivatives of aspirin in human platelets. $\mathrm{Br} J$ Pharmacol 2006, 148:5 I 7-526.

20. Wallace JL: Nitric oxide as a regulator of inflammatory processes. Mem Inst Oswaldo Cruz 2005, I 00(Suppl I):5-9.

21. Graves DT, Jiang Y: Chemokines, a family of chemotactic cytokines. Crit Rev Oral Biol Med 1995, 6:109-I I8.

22. Chang MP, Wisnieski BJ: Comparison of the intoxication pathways of tumor necrosis factor and diphtheria toxin. Infect Immun 1990, 58:2644-2650.

23. Klebanoff SJ, Vadas MA, Harlan JM, Sparks LH, Gamble JR, Agosti JM, Waltersdorph AM: Stimulation of neutrophils by tumor necrosis factor. I Immunol 1986, 136:4220-4225.

24. Dinarello CA, Cannon JG, Wolff SM, Bernheim HA, Beutler B, Cerami A, Figari IS, Palladino MA Jr, O'Connor JV: Tumor necrosis factor (cachectin) is an endogenous pyrogen and induces production of interleukin I. J Exp Med 1986, I 63: |433-1450.
25. Baldwin AS Jr: The NF-kappa B and I kappa B proteins: new discoveries and insights. Annu Rev Immunol 1996, I 4:649-683.

26. Kubes $P$, McCafferty DM: Nitric oxide and intestinal inflammation. Am J Med 2000, I09: I50-I 58

27. Totzke G, Essmann F, Pohlmann S, Lindenblatt C, Janicke RU, SchulzeOsthoff K: A novel member of the Ikappa B family, human Ikappa B-zeta, inhibits transactivation of p65 and its DNA binding. J Biol Chem 2006.

28. Oono H, Nakagawa M, Miyamoto A, Ishiguro S, Nishio A: Mechanisms underlying the enhanced elevation of IL-Ibeta and TNF-alpha mRNA levels following endotoxin challenge in rat alveolar macrophages cultured with low-Mg2+ medium. $\begin{array}{llll}\text { Magnes } & \text { Res 2002, } & \end{array}$

29. Laufer S, Greim C, Bertsche T: An in-vitro screening assay for the detection of inhibitors of proinflammatory cytokine synthesis: a useful tool for the development of new antiarthritic and disease modifying drugs. Osteoarthritis Cartilage 2002, 10:961-967.

30. Bleeker MW, Netea MG, Kullberg BJ, Ven-Jongekrijg J Van der, Meer JW Van der: The effects of dexamethasone and chlorpromazine on tumour necrosis factor-alpha, interleukin-I beta, interleukin-I receptor antagonist and interleukin-10 in human volunteers. Immunology 1997, 9 1:548-552.

31. Barnes PJ: Corticosteroid effects on cell signalling. Eur Respir J 2006, 27:413-426.

32. Adcock IM, Ito K, Barnes PJ: Glucocorticoids: effects on gene transcription. Proc Am Thorac Soc 2004, I:247-254.

33. Adcock IM, Caramori G, Ito K: New insights into the molecular mechanisms of corticosteroids actions. Curr Drug Targets 2006, 7:649-660.

34. Hachicha M, Pouliot M, Petasis NA, Serhan CN: Lipoxin (LX)A4 and aspirin-triggered I5-epi-LXA4 inhibit tumor necrosis factor Ialpha-initiated neutrophil responses and trafficking: regulators of a cytokine-chemokine axis. J Exp Med 1999, 189:1923-1930.

35. Hattori Y, Kasai K, Gross SS: NO suppresses while peroxynitrite sustains NF-kappaB: a paradigm to rationalize cytoprotective and cytotoxic actions attributed to NO. Cardiovasc Res 2004, 63:31-40.

36. Khan Q, Mehta JL: Relevance of platelet-independent effects of aspirin to its salutary effect in atherosclerosis-related events. J Atheroscler Thromb 2005, I 2: 185-190.

37. Kopp E, Ghosh S: Inhibition of NF-kappa B by sodium salicylate and aspirin. Science 1994, 265:956-959.

38. Matthews JR, Botting CH, Panico M, Morris HR, Hay RT: Inhibition of NF-kappaB DNA binding by nitric oxide. Nucleic Acids Res 1996, 24:2236-2242.

39. Sekkai D, Aillet F, Israel N, Lepoivre M: Inhibition of NF-kappaB and HIV-I long terminal repeat transcriptional activation by inducible nitric oxide synthase 2 activity. J Biol Chem 1998 , 273:3895-3900.

40. Tegeder I, Pfeilschifter J, Geisslinger G: Cyclooxygenase-independent actions of cyclooxygenase inhibitors. FASEB J 200I, I 5:2057-2072.

4I. Welters ID, Fimiani C, Bilfinger TV, Stefano GB: NF-kappaB, nitric oxide and opiate signaling. Med Hypotheses 2000, 54:263-268.

42. Yin MJ, Yamamoto Y, Gaynor RB: The anti-inflammatory agents aspirin and salicylate inhibit the activity of I(kappa)B kinasebeta. Nature 1998, 396:77-80.

43. Ward C, Chilvers ER, Lawson MF, Pryde JG, Fujihara S, Farrow SN, Haslett C, Rossi AG: NF-kappaB activation is a critical regulator of human granulocyte apoptosis in vitro. J Biol Chem 1999, 274:4309-4318.

44. Rossi AG, McCutcheon JC, Roy N, Chilvers ER, Haslett C, Dransfield I: Regulation of macrophage phagocytosis of apoptotic cells by CAMP. J Immunol 1998, I60:3562-3568.

45. Bournazos S, Rennie J, Hart SP, Fox KA, Dransfield I: Monocyte Functional Responsiveness After PSGL-I-Mediated Platelet Adhesion Is Dependent on Platelet Activation Status. Arterioscler Thromb Vasc Biol 2008, 28(8): | 49|-|498.

46. Nishibe T, Parry G, Ishida A, Aziz S, Murray J, Patel Y, Rahman S, Strand K, Saito K, Saito $Y$, et al.: Oncostatin M promotes biphasic tissue factor expression in smooth muscle cells: evidence for Erk-I/2 activation. Blood 200I, 97:692-699.

47. Feng H, Li XY, Zheng JR, Gao JW, Xu LF, Tang MY: Inhibition of the nuclear factor-kappaB signaling pathway by leflunomide or 
triptolide also inhibits the anthralin-induced inflammatory response but does not affect keratinocyte growth inhibition. Biol Pharm Bull 2005, 28: 1597-1602.

48. Mitchell JA, Saunders M, Barnes PJ, Newton R, Belvisi MG: Sodium salicylate inhibits cyclo-oxygenase-2 activity independently of transcription factor (nuclear factor kappaB) activation: role of arachidonic acid. Mol Pharmacol 1997, 5 I:907-9|2.

49. Osnes LT, Foss KB, Joo GB, Okkenhaug C, Westvik AB, Ovstebo R, Kierulf $P$ : Acetylsalicylic acid and sodium salicylate inhibit LPS-induced NF-kappa B/c-Rel nuclear translocation, and synthesis of tissue factor (TF) and tumor necrosis factor alfa (TNF-alpha) in human monocytes. Thromb Haemost 1996, 76:970-976.

50. Minuz P, Degan M, Gaino S, Meneguzzi A, Zuliani V, Santonastaso CL, Soldato PD, Lechi A: NCX40I6 (NO-Aspirin) has multiple inhibitory effects in LPS-stimulated human monocytes. $\mathrm{Br} J$ Pharmacol 2001, I 34:905-911.

5I. Rosenkranz B, Frolich JC: Plasma concentrations and anti-platelet effects after low dose acetylsalicylic acid. Prostaglandins Leukot Med 1985, 19:289-300.

52. Fiorucci S, Santucci L, Cirino G, Mencarelli A, Familiari L, Soldato PD, Morelli A: IL-I beta converting enzyme is a target for nitric oxide-releasing aspirin: new insights in the antiinflammatory mechanism of nitric oxide-releasing nonsteroidal antiinflammatory drugs. J Immunol 2000, 165:5245-5254.

53. Hart PH, Bonder CS, Balogh J, Dickensheets HL, Donnelly RP, FinlayJones Jj: Differential responses of human monocytes and macrophages to IL-4 and IL-13. J Leukoc Biol 1999, 66:575-578.

54. Barbour SE, Wong C, Rabah D, Kapur A, Carter AD: Mature macrophage cell lines exhibit variable responses to LPS. Mol Immunol 1998, 35:977-987.

55. Rao KM: MAP kinase activation in macrophages. J Leukoc Biol 200I, 69:3-10.

56. Monick MM, Carter AB, Gudmundsson G, Geist LJ, Hunninghake GW: Changes in PKC isoforms in human alveolar macrophages compared with blood monocytes. Am J Physiol 1998, 275:L389-397.

57. Herzyk DJ, Allen JN, Marsh CB, Wewers MD: Macrophage and monocyte IL-I beta regulation differs at multiple sites. Messenger RNA expression, translation, and post-translational processing. J Immunol 1992, 149:3052-3058.

58. Panwalkar A, Verstovsek S, Giles F: Nuclear factor-kappaB modulation as a therapeutic approach in hematologic malignancies. Cancer 2004, 100:1578-1589.

59. Ghosh S, May MJ, Kopp EB: NF-kappa B and Rel proteins: evolutionarily conserved mediators of immune responses. Annu Rev Immunol 1998, 16:225-260.

60. Yamamoto Y, Gaynor RB: IkappaB kinases: key regulators of the NF-kappaB pathway. Trends Biochem Sci 2004, 29:72-79.

61. Kaltschmidt B, Sparna T, Kaltschmidt C: Activation of NF-kappa B by reactive oxygen intermediates in the nervous system. Antioxid Redox Signal 1999, I: I29-144.

62. Liu H, Sidiropoulos P, Song G, Pagliari LJ, Birrer MJ, Stein B, Anrather J, Pope RM: TNF-alpha gene expression in macrophages: regulation by NF-kappa B is independent of c-Jun or C/EBP beta. J Immunol 2000, 164:4277-4285.

63. Pahl HL, Krauss B, Schulze-Osthoff K, Decker T, Traenckner EB, Vogt $M$, Myers C, Parks T, Warring P, Muhlbacher A, et al:: The immunosuppressive fungal metabolite gliotoxin specifically inhibits transcription factor NF-kappaB. J Exp Med 1996, 183:1829-1840.

64. Carroccio A, Di Prima L, Pirrone G, Ambrosiano G, Noto D, Cefalu $A B:$ [Anti-TNF (infliximab) treatment in Crohn disease: safety profile]. Recenti Prog Med 2006, 97: I08-I I2. quiz I22.

65. Christodoulou $\mathrm{C}$, Choy $\mathrm{EH}$ : Joint inflammation and cytokine inhibition in rheumatoid arthritis. Clin Exp Med 2006, 6: 13-19.

66. Russo C, Polosa R: TNF-alpha as a promising therapeutic target in chronic asthma: a lesson from rheumatoid arthritis. Clin Sci (Lond) 2005, 109:135-142.

67. Siddiqui MA, Scott LJ: Spotlight on infliximab in Crohn disease and rheumatoid arthritis. BioDrugs 2006, 20:67-70.

68. Turnbull CM, Rossi AG, Megson IL: Therapeutic effects of nitric oxide-aspirin hybrid drugs. Expert Opin Ther Targets 2006, 10:911-922.

69. Ross R: Atherosclerosis - an inflammatory disease. N Engl J Med 1999, 340: II5-126.
70. Pober JS, Cotran RS: Cytokines and endothelial cell biology. Physiol Rev 1990, 70:427-45I.

7I. Libby P, Sukhova G, Lee RT, Galis ZS: Cytokines regulate vascular functions related to stability of the atherosclerotic plaque. $J$ Cardiovasc Pharmacol 1995, 25(Suppl 2):S9-12.

72. Galis ZS, Muszynski M, Sukhova GK, Simon-Morrissey E, Unemori EN, Lark MW, Amento E, Libby P: Cytokine-stimulated human vascular smooth muscle cells synthesize a complement of enzymes required for extracellular matrix digestion. Circ Res 1994, 75:181-189.

73. Geng YJ, Wu Q, Muszynski M, Hansson GK, Libby P: Apoptosis of vascular smooth muscle cells induced by in vitro stimulation with interferon-gamma, tumor necrosis factor-alpha, and interleukin-I beta. Arterioscler Thromb Vasc Biol 1996, 16:19-27.

74. Jovinge S, Crisby M, Thyberg J, Nilsson J: DNA fragmentation and ultrastructural changes of degenerating cells in atherosclerotic lesions and smooth muscle cells exposed to oxidized LDL in vitro. Arterioscler Thromb Vasc Biol 1997, 17:2225-2231.
Publish with Bio Med Central and every scientist can read your work free of charge

"BioMed Central will be the most significant development for disseminating the results of biomedical research in our lifetime. "

Sir Paul Nurse, Cancer Research UK

Your research papers will be:

- available free of charge to the entire biomedical community

- peer reviewed and published immediately upon acceptance

- cited in PubMed and archived on PubMed Central

- yours - you keep the copyright

Submit your manuscript here:

http://www.biomedcentral.com/info/publishing_adv.asp
BioMedcentral 